\title{
Nash's Virus-infected Narrative: The Hermeneutic and Metaphoric Narrative Drives in The Unfortunate Traveller
}

\author{
Bahee Hadaegh \\ Assistant Prof., Shiraz University, Department of English Literature \\ Elmira Molaii \\ M.A. Student, Shiraz University, Department of English Literature
}

Doi:10.5901/mjss.2015.v6n3s2p453

\begin{abstract}
The present paper aims to explore the narrative of The Unfortunate Traveller by Thomas Nash apart from the normative assessments of most critics by and large based on grand plot criteria. Thus, the chief concern of this study is not as much about the issues of coherence and thematicism than temporal dynamics of the text; that which controls the desire to further read the text. What is more, this narrative is to be analyzed within the framework of grave plot whose pivotal focus is on the space in contrast to the conventional concerns of linearity and chronology of the narrative dominated by a logical structure and thematic purpose. To this end, drawing upon Peter Brooks's narratological theory, this novel would be set within a triadic framework including the plotting, the desire of the text, and the issue of transference. Consequently, such analysis would help to shed light on and get at the heart of the narrative structure with relation to the hermeneutic forces that determine the observance of the text and its lack of structural logicality on the one hand and the relation between narrator-reader with regards to the futility of narrative therapy on the other.
\end{abstract}

Keywords: The Unfortunate Traveller, Thomas Nash, Grave plot, Peter Brooks, Plotting, Desire, Hermeneutic forces, Narrative therapy.

\section{Introduction}

No narrative written in Renaissance has given as much rise to unfavorable response as The Unfortunate Traveller whether then or now. Much of the debate is around the fact that this narrative does not abide by the standards of the true novel which is to say it lacks a coherent plot and does not centers on any unified subject. This controversy can be solved once and for all if the narrative is examined by a different approach than a true for all method of narrative of chronology and theme. To this purpose this study aims to explore the narratology of the Unfortunate Traveller in the light of Peter Brooks's approach toward the plotting, the desire of the text and eventually the issue of transference.

Despite the general view about the plot which "meanders haphazardly through episodes, descriptions, and anecdotes that appear to be extraneous and irrelevant to the progress of the narrative" (Stephanson 21) and what we quite often hear about the narrative "incoherence"; incapability of the text for any classification and the fact that "it embodies nothing that can be called a view of life" (Stephanson 21), this text and its plot herein is to be analyzed by different criteria. There is no tremor on the fact that there occurs a major shift in the attitude of the narrator in his elaboration as the story moves forward; however this shift and other plot-theme claims are not and indeed cannot be deciphered by the standards of what is regarded as the true novel.

Brooks turns to "the temporal dynamics that shape narratives in our reading of them, the play of desire in time that makes us turn pages and strive toward narrative ends" (Felluga online). He is interested in "the motor forces that drive the text forward, of the desires that connect narrative ends and beginnings, and make of the textual middle a highly charged field of force" (Felluga online). In addition he is concerned with "'a work's boundedness, the ways it demarcates, encloses, establishes limits, orders'" (Felluga online). As a result, Brooks also reads "plot" in the sense suggested by a grave plot: a bounded space, one that is, indeed, intimately tied with questions of death, or at least closure; in other words, Brooks reads plot as following "the internal logic of the discourse of mortality" (Felluga online). Though Brooks discusses the "hermeneutic-praoiretic" and "metaphoric-metonymic" forces of the plot, in so static a plot we are more faced with the hermeneutic and metaphoric drives. 


\subsection{Significance}

This study signifies that there is no true for all criteria for analyzing a novel, be it written in renaissance or in the modern period. In order to understand the merits of a novel such as this, whereof many contradictory critical responses arise, a novel approach is required; one which would best fit its structure.

\subsection{Objective}

The prominent goal in this study is to resolve the dilemma concerning the structure of the narrative with regard to the reader's reaction to the text and how the text in its own turn conditions the reader's response while at the same time, through a piecemeal analysis of the novel, it aims to get at the heart of the basic cause for the absence of mutual interaction between the aforementioned poles.

\subsection{Methodology and its choice}

This paper benefits mainly from narratology. Prominent among narratologists is Peter Brooks whose views on the tripartite structure of the narrative including plotting which concerns the temporal engagement of the reader, desire of the text whether toward metaphoric or metonymic figures and finally transference with regard to the passing of the narrative wounds onto the reader, provides the single major source from which this study benefits a great deal. The choice of this method is primarily due to its connection to psychology of the text; how it contributes to explain the psychological disintegration of the narrator as well as the reader, as Brooks has adopted Freudian psychoanalysis in his brand of narratology, and its concerns about grand narrative with its ignorance of conventional bias toward a sequential standard of plot so much in correspondence with space-bound structure of the novel.

\section{Discussion}

After the initial narratives of Jack's wit, who resorts to "the fox's case while the lion's skin is out at the elbows" (Nash 5), where the focus is on the action of the plot accompanied by metonymic sense of humor, the narrative shifts its trend thenceforth every other detailed account of itzeroes in on why rather than what comes next or so. For example at first the reader is more absorbed in the course of events that he or she wants to know what comes of the cider merchant after Jack's lies to him or the captain who is deceived by him and is put in a deadlock both in France or in England. Such a transition from the proairetic to the hermeneutic cycle and to the point where the narrative becomes more of the "grave plot" than the "narrative plot" (Felluga online)-- which is space-bound or metaphoric rather than time-bound-- accounts for the delineation of the plot as"an interesting artistic failure" by "general consensus"(Stephanson 22). Croston refers to this space-bound aspect of the narrative as he notes: "The chief characteristic ofNashe's prose is its alertness to the possibilities of metaphor"(90).

Besides this alteration from what to why; action to reason; and time to space, he mixes his plot with more of abject violence. And since the narrative stance takes a definite attitude neither toward the victims nor the victimizers, this quality, categorically leaves the text open to criticism and accusation for lack of purpose, subject, ending soon and so forth. The paradox lies in the fact that this narrative yearns for ending in each word, phrase, sentence, paragraph and so on from the very beginning of the narrative depiction. A simple example for the confusion due to lack of a specific point of view is the point at which "Critics are divided on the question of implicit collaboration in, or victimization by the events... in both the relation of the slaughter of the Anabaptists and the rape of Heraclide" (Nash34). To this you can add the violence of the killer, the rapist and the avenger. In Ossa-Richardson's words "over-elaborated metaphor" is one of the methods by which the violence shows up (946). Thus Jack's metaphors take an aura of violence and abject disgust of which his use of urine for blood and his tears or his substitution of his innermost secrets with his breast turned outward are among others: "I bade him [the merchant] harden his ears, and not make his eyes abortive before their time, and he should have the inside of my breast turned outward" (Nash 7).While in another case he says: "Why (quoth I), myself that am but a poor childish well-willer of yours, with the very thought that a man of your desert and state by a number of peasants and varlets should be so injuriously abused in hugger-mugger, have wept all my urine upwards" (Nash 7).

These depictions accent the materiality and physicality of human beings; in other words they give a picture of the ugly disgusting aspect of being rather than the beautiful side of materiality and humanity. "There is only one term to describe Nash's language of distortion: the grotesque"(Stephanson 33). Such distortions and violent disposition adds up to challenging the general expectations of the readers from the text. As mentioned before the text includes metaphoric 
inclinations more than metonymic ones. It is this closural metaphor that Brooks aligns to thanatos as one of the major driving forces of every narrative whose opposite side is the metonymy or eros(Felluga online). Moreover he holds that the dilations of the narrative account for and make meaningful the ending; therefore he associates the former to the life instinct and the latter to the death instinct. That is "Narrative desire is, therefore, ultimately, 'desire for the end', although any narrative also requires the dilations and transformations of the middle to make such an end desirable" (Felluga online).

Normally every reading is undertaken for some view of life one way or another. This can easily account for the huge disfavorable responses to the text since Nash's text is metaphoric and concerned more with the ending rather than the beginning, with thanatos rather than eros. Put it another way the desire of the narrative is that of the death instinct when its opposite is more favorable for any reader. Everything including the scripture for Jack is to be deathward: "That scripture then was not thought so necessary which says, Earn thy living with the sweat of thy brows, for then they earned their dying with the sweat of their brows" (Nash 15). Death is everywhere: "one place might you behold a heap of dead murdered men overwhelmed with a falling steed instead of a tombstone, in another place a bundle of bodies fettered together in their own bowels, and as the tyrant Roman emperors used to tie condemned living caitiffs face to face to dead corses, so were the half living here mixed with squeezed carcasses long putrified" (Nash 16).

Put aside the disgusting death of Zadoch, one will have the death of Heraclide imprinted upon one's mind forever. "Ah, quoth Heraclide (with a heart-rending sigh), art thou ordained to be a worse plague to me than the plague itself? Have I escaped the hands of God to fall into the hands of man?" (Nash 47). The closural metaphor is that here the vehicle is the plague and the tenor is man. While formerly he depicted the man as the victim of death, he calls him the plague itself-- hence the cause of death. In addition to the deathward content of the story, the narrative itself has its deathward tendencies revealed often-times. As Jack claims: "This tale must at one time or other give up the ghost..." (Nash 22). And in another instance he declares: "Whatsoever is born, is born to have an end. Thus ends my tale; his whorish lust was glutted, his beastly desire satisfied; what in the house of any worth was carriageable, he put up, and went his way" (Nash 49).

In very rare cases in this text there is to be found examples of life with all its lively qualities. One is Jack's depiction of a house in Rome as he saw:

A summer banqueting house belonging to a merchant that was the marvel of the world, and could not be matched except God should make another paradise. It was built round of green marble like a theatre without; within there was a heaven and earth comprehended both under one roof: the heaven was a clear overhanging vault of crystal wherein the sun and moon and each visible star had his true similitude, shine, situation and motion, and, by what enwrapped art I cannot conceive, these spheres in their proper orbs observed their circular wheelings and turnings, making a certain kind of soft angelical murmuring music in their often windings and going about, which music the philosophers say in the true heaven, by reason of the grossness of our senses, we are not capable of. For the earth, it was counterfeited in that likeness that Adam lorded out it before his fall. (Nash 44)

The next instance is when he talks of the world with all its organisms before Adam's time. "The ant did not hoard up against winter, for there was no winter, but a perpetual spring, as Ovid saith. No frosts to make the green almond tree counted rash and improvident in budding soonest of all other, or the mulberry tree a strange politician, in blooming late and ripening early" (Nashe 49). It is no wonder then to encounter many views as incompatible as Jone's who claims: "Nashe, however, has no structural or ethical purpose in detailing the ravages of plague and warfare, or the fantastic refinements of his executioners' arts; his effects of gory realism are reached 'through the ... artistic effort of a writer who considers deadly violence as a subject among others'" (66). In another place Sulfridge mentions "The experience-- the sensation-- itself was the text. This is what C. S. Lewis called Nash's "pure' literature: literature which is, as nearly as possible, without a subject. In a certain sense of the verb 'say', if asked what Nash 'says', we should have to reply, Nothing"'(14).

In the first case, regarding the structural purposelessness; conversely the narrative has a structural purpose which is that of closure and thanatos which is absolutely in harmony with the narration of each narrative and the deathward content itself. As Hyman puts it "From the height of tragedy to the depths of farce, Wilton's wilted narrative has only "dyed" insofar as Esdras's has..." (33). It means that the narrative's death is in interactive balance with and direction toward the victims and victimizers as well as the main content itself. Thus the text inclination is into thanatos, not merely an experience and by no means about nothing, contrary to the second case view mentioned by Lewis, but about an instinct and perception behind the psyche of Jack which pushes him toward the ending even while the beginning barely has been started.

For Jack if there is any sign of real life, it belongs to the bygone past before Adam or it is in an ideal shape of a paradise or something. He sees the dark side of the world and its unchanging monotonous rhythm. So goes his view of 
life rampant here and there:

What is there in France to be learned more than in England but falsehood in fellowship, perfect slovenry, to love no man but for my pleasure, to swear Ah, par la mort Dieu when a man's hams are scabbed. For the idle traveller (I mean not for the soldier), I have known some that have continued there by the space of half a dozen years, and when they come home they have hid a little wearish lean face under a broad French hat, kept a terrible coil with the dust in the street in their long cloaks of grey paper, and spoke English strangely. (Nash 53)

Then you might ask yourself what for does Jack ramble on and on once he is well aware that not a new lesson is to stem from any one of those stories he mention and keep telling and retelling same ugly features of our life and ourselves only by changing names and contexts while keeping the structural desire and its death-concerned content fixed? If you approach what happened to Jack as tightly implicated within Brook's idea of narrative transference, you probably would get a firm grasp as to why the narrator goes on about telling and retelling things purposelessly without thematic concerns.

In the first place, Jack is urged by the "fevered need to retell" (Felluga online) and in the second, "the passing of the virus of the narrative". Jack feels the urge to retell what he once has experienced or witnessed as an observer. This urgency aims to work his traumatic obsessions out toward a rather different closure-- the drive which gets us to listen till the establishment of the closural end (Felluga online). Brooks likens the relationship between the analyst and the analysand to that of the listener and the narrator (Felluga online) while from his angle this interactive dialogue creates a kind of "talking cure" for the latter. In fact, the role of the analyst or the listener is to get the analysand to recognize the past as past rather than the present so as to terminate the repetitive narration and remembrance of the past towards progression in life (Felluga online).

Since this interaction is mutually constitutive, if one fails, so does the other. In order to understand why the reader is left unsettled by the end of the tale we should make an account of Jack's success or fiasco throughout his journey. Gahlke claims that Jack remains untouched by his surrounding events:

Although Jack en-counters one horror after another in his travels (sickness, torture, massacre, rape, execution), he emerges from them remarkably untouched. The key to his invulnerability lies in his switch from an active to a passive role, from participant in events to narrator of events. (407)

To the contrary, though physically untouched, Jack suffers deep emotional wounds from his observation while even after narrating his travel story still he declares, "my crumbs among the cardinals, to implore the benevolence and charity of all the dukes of Italy, whereby I have since made a poor shift to live, but so live as I wish myself a thousand times dead" (Nashe 54). And in another instance he mentions how much "abjected and undaunted" he was for the sight of murders as one summed on and impringed upon the next (Nashe 68). The double sense of abjection and undaunted observance points out to Jack's mixed feelings as he is simultaneously touched emotionally; however physically remains untouched as an eyewitness. Thus Jack ends where he began, "so as my story began with the King at Tournay and Terouanne, I think meet here to end it with the King at Ardres and Guines" (Nashe 68).

None of the frame tale narrators, the participants, so to speak, provide him with therepuatic cure. They are either dead or on the verge of dying. He does not act as a soothing listener either inasmuch as he is exposed to overhearing. Hence lack of mutuality of interactive passing on the wounds, he fails to help the victims and in turn he falls prey to the same wound he witnessed. Therefore, he takes a Shahrazadian stance neither for the victimizers nor for the victims. Thus this failure makes him undergo the compulsion to repeat so as to work out the unresolved tensions passed on to him.

Just as Jack falls prey to his unresolved complications of his journey, so does the reader and listener of his story. As Sulfridge puts it, in this text the boundaries between the "textual time" and the "reader time" are immersed (5). This is what categorically gives the reader a borderline identity. Sulfridge's conviction on the reader-narrator identification is as follows:

Jack, whom initially the reader finds likable, now shows signs that there is another side to his nature. At first the reader can laugh easily at Jack's jests and can even accept a certain intimacy with the persona himself. But as the narrative progresses, though Jack keeps insisting upon his tone of familiarity with the reader, he and his attitudes become more and more difficult for the reader to identify with. (7)

However, unlike this conviction, one should not forget that if the reader does not identify with Jack's attitudes, they certainly do identify with him till the end as he is the eyes through which every episode and tale is framed and reframed. In other words Jack's eyes are the windows and the only tools by which the reader observes, in turn infected by the same virus, and enacts each episode both as the victim and the victimizer.As Croston points out,"apart from sheer metaphoric zest the performance aims at giving the reader the sense of immediate physical action"(90-91). This refers to the text double function and its giving rise to the reader's dyadic role-playing which is, just similar to Jack's case, the enactment of passive and active roles in the reading process accounting for the victim-victimizer stances. The reader's borderline 
identity pushes him or her toward two alternatives: one is turning away from the narrative and the other is turning to the narrative. Sulfridge's conviction about power of the text over the reader is mentioned this way: "Short of putting the book down and the experience out of his mind, the reader has no way to free himself from what has become a relationship of increasing discomfort" (13).

However, conversely the reader has as one of his or her alternatives the choice of either putting down the book or returning to the text, though not without its consequences in each case. In the first case since the closing of the book is no equivalence for the closural sense of finishing the book, it only provides a temporary detachment from the text without elimination of the subsisting problem. On the other hand, stepping back to the text is not without its aftereffects. According to Norman Holland if a text is providing us with outlets for our primitive instinctual expressions, it should as well protect us against the resurfacing of such pristine instincts (106). As the key failure of this text is lack of a protective fence for so abject and taboo senses, this second alternative is bound to doom likewise. Hence the non-presence of the "adaptive strategy" (Holland 8) gets the reader to seek closure by taking the trouble to read the story to its bitter end.

\section{Conclusion}

To put it briefly, it must be noted that as a non-traditional narrative this text should be approached with caution, not to be judged by standards of traditional formal-thematic concerns, to do it justice. As to the form and theme, it is worth mentioning that this novel is framed by the metaphor of death and the theme of death likewise. What actually challenges the readers of this novel is not the fragmentary style or lack of a pragmatic conclusion, instead what unsettles them is the text's lack of success to provide them with a releasing cure and therapy, their enactment of the taboo and the inhibited boundaries of the self deeper facets to the point of playing even the role of the victimizer, a murderer, and the victim. This brutal overstepping of the boundaries; enactment of death to the end of the narrative brings all the structural, formal, thematic, reader-cum-writer elements in a single point-- all partaking in closure, though an unsuccessful one, hence the absence of an unfettering outlet to the destructive side of the psyche from which everyone demands freedom.

\section{References}

Croston, A. K. (1948), "The Use of Imagery in Nash's The Unfortunate Traveller." The Review of English Studies 24.94: 90-101. Pdf. Felluga, Dino. (2014), "Modules on Narratology." Introductory Guide to Critical Theory. Purdue U. July 10. Web.

Gohlke, Madelon S. (1976), "Wits Wantonness: The Unfortunate Traveller as Picaresque." Studies inPhilology 73.4: 397-413.Pdf.

Holland, Norman. (1968), The Dynamics of Literary Response. New York: Oxford Univ. Press, Pdf.

Hyman, Wendy. (2005), "Authorial Self-Consciousness in Nash's The Unfortvnate Traveller." Studies in English Literature 45.1: 2341.Pdf.

Jones, Ann R. (1983),"Inside the Outsider: Nash's Unfortunate Traveller and Bakhtin's Polyphonic Novel." ELH 5.1: 61-81.Pdf.

Nash, Thomas. (2002), The Unfortunate Traveller or The Life of Jack Wilton. Ed.Nina Green. London: Modern Spelling, Pdf.

Ossa-Richardson, Anthony. (2006),"The 'free play with signs' in Thomas Nash's The Unfortunate Traveller."The Modern Language Review 101:4 945-956. Pdf.

Stephanson, Raymond. (1983) "The Epistemological Challenge of Nash's The Unfortunate Traveller." Studies in English Literature 23.1: 21-36. Pdf.

Sulfridge, Cynthia. (1980),"The Unfortunate Traveller. Nashe's Narrative in a 'Cleane Different

Vaine'." The Journal of Narrative Technique 10:11-15. Pdf. 